\title{
PAYMENT APPLICATION DESIGN USING CART (CLASSIFICATION AND REGRESSION TREE) METHOD
}

\section{PERANCANGAN APLIKASI PENGGAJIAN MENGGUNAKAN METODE CART (CLASSIFICATION AND REGRESSION TREE)}

\author{
Elfinda Lusiana Ika Pradita ${ }^{1}$, Kurnia Paranita Kartika ${ }^{2}$, Filda Febrinita ${ }^{3}$ \\ elfindalusiana@gmail.com ${ }^{1}, \underline{\text { kurnia.paranitha@gmail.com }}{ }^{2}, \underline{\text { febrinitafilda80@gmail.com }}{ }^{3}$ \\ Program Studi Teknik Informatika, Fakultas Teknologi Informasi, \\ Universitas Islam Balitar
}

\begin{abstract}
This payroll application is used to calculate the amount of salary that will be received by the Lion Parcel Blitar courier. This study aims to help find solutions for admins to complete payroll tasks quickly and accurately by developing a payroll system that is easy to implement. This research uses the RND (Research and Development) method according to Sugiyono (2012), because this method is used to generate and test the effectiveness of a product. To facilitate the grouping of couriers delivering the most packages and delivering the least packages, the method used by the author in this study is the CART method with the final result being a confusion matrix class a $(<=600)$ of 5 data and a confusion matrix of class $b(>600)$ of 3 data. In addition, Black Box testing is also used with a percentage of $92.3 \%$ and questionnaires to validators of $86.1 \%$, as well as prospective users as testing applications with a percentage of $90.4 \%$. So this application is declared very feasible.
\end{abstract}

Keywords: Payroll application, RND (Research and Development), CART (Classification and Regression Tree), Black Box Testing.

Abstrak. Aplikasi penggajian ini digunakan untuk menghitung besaran gaji yang akan diterima oleh kurir Lion Parcel Blitar. Penelitian ini bertujuan untuk membantu mencarikan solusi kepada admin untuk menyelesaikan tugas penggajian secara cepat, dan akurat dengan membuatkan sistem penggajian yang mudah di implementasikan. Penilitian ini menggunakan metode RND (Research and Development) menurut Sugiyono (2012), karena metode ini digunakan untuk menghasilkan dan menguji keefektifan dari sebuah produk. Untuk memudahkan pengelompokan kurir pengantar paket terbanyak dan pengantar paket paling sedikit, maka metode yang digunakan penulis dalam penelitian ini adalah metode CART dengan hasil akhir confusion matrix kelas a $(<=600)$ sebesar 5 data dan confusion matrix kelas b ( > 600 ) sebesar 3 data. Selain itu digunakan juga pengujian Black Box dengan presentase 92.3\% dan kuisioner kepada validator sebesar $86.1 \%$, maupun calon pengguna sebagai pengujian aplikasinya dengan presentase sebesar $90.4 \%$. Sehingga aplikasi ini dinyatakan sangat layak.

Kata kunci: Aplikasi penggajian, RND (Research and Development), CART (Classification and Regression Tree), Black Box Testing.

\section{Pendahuluan}

Sistem penggajian dilakukan di CV. Manunggal Sakti. CV. Manunggal Sakti merupakan perusahaan yang bergabung dengan ekspedisi Lion Parcel. Lion Parcel sendiri merupakan salah satu unit bisnis usaha Lion Group yang bergerak di bidang ekspedisi atau jasa pengiriman barang door to door service yang berdiri pada tahun 2013. Dalam melakukan pengantaran paket atau barang ke rumah customer, perusahaan membutuhkan beberapa tenaga kurir. Setiap kurir yang membawa dan mengantar paket dengan jumlah yang berbeda, maka gaji yang akan diterima juga berbeda.

CV. Manunggal Sakti bergabung dengan Lion Parcel pada tahun 2017 dan perusahaan ini baru berkembang di tahun 2019, dikarenakan masih tergolong perusahaan baru, maka perhitungan gaji kurir Lion Parcel masih manual, sistem penggajian kurir juga belum ada. Sebelumnya setiap tanggal merah, pengantaran barang selalu ditiadakan atau dalam artian kurir libur, namun pada pertengahan tahun 2020, Manajemen Lion Parcel Pusat menginformasikan kepada seluruh Konsolidator/Subkonsolidator untuk tetap melakukan delivery di hari libur. Hal ini membuat pimpinan CV. Manunggal Sakti menginginkan pengadaaan bonus bagi kurir yang bersedia masuk setiap hari. Selain itu, pimpinan CV. Manunggal Sakti juga mengharapkan adanya pemberian reward kepada kurir yang berhasil menuntaskan pengataran paket dalam sehari berupa uang lembur.

Dalam pengerjaannya admin Lion Parcel merekap gaji kurir menggunakan bantuan Microsoft Excel dengan cara entry manual sehingga sangat beresiko apabila terdapat kesalahan dalam pengetikkan. Untuk meminimalisir 
terjadinya kesalahan saat memproses gaji kurir, maka penulis akan membuatkan perancangan aplikasi penggajian yang diharapkan dapat membantu meningkatkan kinerja admin Lion Parcel. Pada perancangan ini, penulis menggunakan metode CART (Classification and Regression Tree).

Metode CART (Classification and Regression Tree) pertama kali dikenalkan oleh Leo Breiman et. al. tahun 1984. Penulis memilih metode ini untuk memecahkan persoalan dalam penghitungan gaji kurir dikarenakan menurut Zain, dkk. (2014) hasil dari perhitungan dengan metode ini lebih mudah diinterpretasikan, lebih cepat dan lebih akurat. Metode CART juga bisa digunakan untuk himpunan data dan variabel dalam jumlah besar, dan dengan skala variabel campuran melalui prosedur pemilahan biner (Zain, Pratiwi, \& Ismaini, 2014).

Aplikasi penggajian kurir Lion Parcel ini menggunakan Metode CART dan diharapkan dapat membantu dalam penyelesaian masalah pengerjaan gaji pokok, uang pulsa dan uang transport serta tunjangan lain seperti pembayaran bonus karyawan, gaji lembur, uang pulsa, fee pengantaran dan fee pickup. Keunggulan dari aplikasi ini yaitu dapat membantu sistem gaji di Lion Parcel supaya lebih modern dan sistematis guna memudahkan pimpinan untuk memberikan upah bagi karyawan sesuai yang sudah disepakati sehingga taraf kesejahteraan karyawan bisa lebih di utamakan lagi.

\section{METODE}

Pada perancangan ini peneliti menggunakan metode Research and Development (R\&D) karena metode ini digunakan untuk menghasilkan produk dan menguji keefektifan dari sebuah produk. Pada bagian ini, peneliti hanya melakukan penelitian sampai uji coba produk, dikarenakan untuk perancangan kebutuhannya hanya sampai uji coba produk saja. Model penelitian ini memiliki beberapa tahapan sebagai berikut: a) Potensi dan masalah: Potensi dan masalah yang dikemukakan dalam penelitian ini harus ditunjukkan dengan data yang empirik. Masalah ini bisa diatasi menggunakan metode R\&D dengan cara melakukan penelitian, sehingga bisa ditemukan suatu model, sistem atau pola penanganan yang efektif dan bisa digunakan untuk mengatasi masalah penggajian kurir Lion Parcel di CV. Manunggal Sakti. b) Pengumpulan data: Pengumpulan data atau informasi yang bisa digunakan untuk merencanakan pembuatan rancangan aplikasi penggajian kurir Lion Parcel yang diharapkan dapat membantu pekerjaan admin maupun pimpinan dalam mengelola gaji kurir. Hal ini ditujukan untuk menemukan konsep konsep yang bisa memperkuat rancangan aplikasi tersebut. c) Desain produk: Desain produk pada perancangan aplikasi penggajian kurir Lion Parcel ini masih bersifat hipotetik, karena efektivitasnya masih belum terbukti, dan baru bisa diketahui setelah melewati beberapa pengujian. Desain produk diwujudkan kedalam bentuk gambar atau bagan, sehingga akan memudahkan pihak lain maupun calon user untuk lebih memahaminya. d) Validasi desain: Pengujian algortima CART ini menggunakan aplikasi Weka. Validasi desain dilakukan oleh beberapa ahli seperti ahli desain, dan ahli materi yang sudah berpengalaman untuk menilai kelayakan produk yang dirancang. Tujuan dari validasi desain untuk menilai apakah rancangan desain produk yang akan dibuat sudah sesuai dengan yang diharapkan atau belum. e) Revisi desain: Sesudah divalidasi melalui diskusi bersama para pakar dan para ahli lainnya, maka akan bisa diketahui kelemahannya. Kelemahan pada perancangan aplikasi penggajian kurir Lion Parcel ini kemudian diperbaiki. Yang bertugas memperbaiki desain adalah peneliti yang akan menghasilkan produk tersebut. f) Uji coba produk: Pengujian bisa dilakukan melalui ekperimen, yaitu membandingkan efektivitas dan efesiensi sistem kerja yang lama dengan sistem kerja yang baru. Uji coba produk ini diujikan ke validator dan pimpinan CV. Manunggal Sakti.

Pada perancangan sistem ini, peneliti menggunakan desain Unified Modeling Language (UML) untuk proses pembuatan arsitektur sistem, struktur data dan desain antarmuka sistem yang akan diimplementasikan menjadi sistem pada tahap selanjutnya

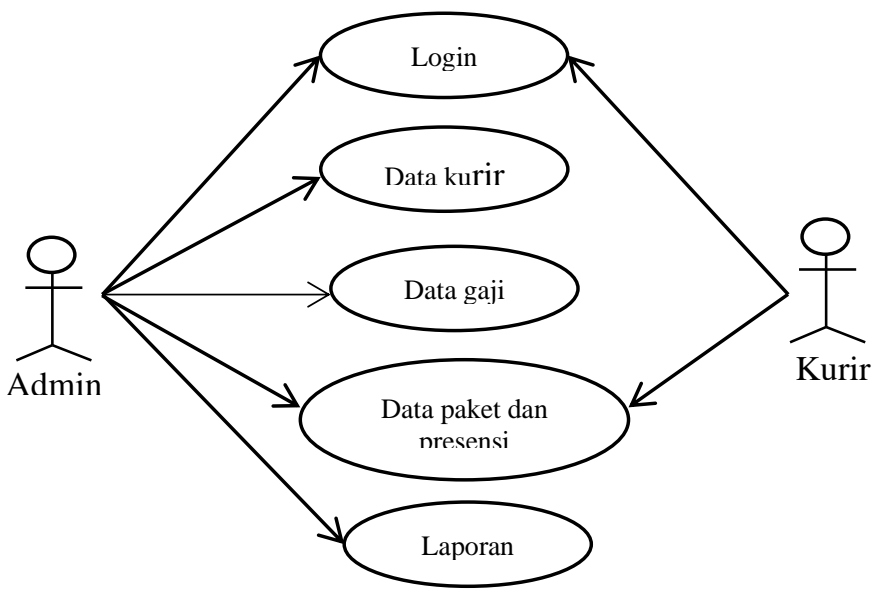




\section{Gambar 1 Use Case Diagram}

Selanjutnya dalam perancangan aplikasi penggajian kurir Lion Parcel di CV. Manunggal Sakti, penulis memilih untuk menggunakan Metode CART (Classification and Regression Tree) dikarenakan hasil dari metode ini mudah diinterpretasikan, perhitungan yang cepat dan hasil yang didapat lebih akurat. Metode CART bisa diterapkan pada kumpulan data dengan penelitian dengan jumlah yang besar. Metode CART merupakan metode dengan teknik pencarian data berstruktur pohon. Metode ini menghasilkan 2 model pohon, yaitu pohon regresi dan pohon klasifikasi. Pohon regresi merupakan model yang digunakan untuk peubah respons berupa peubah kontinu atau berlanjut, sedangkan pohon regresi merupakan model untuk peubah respon berupa peubah kategorik. Dalam proses pembentukan pohon klasifikasi ini dilakukan secara rekursif. Berikut flowchart dari metode CART:

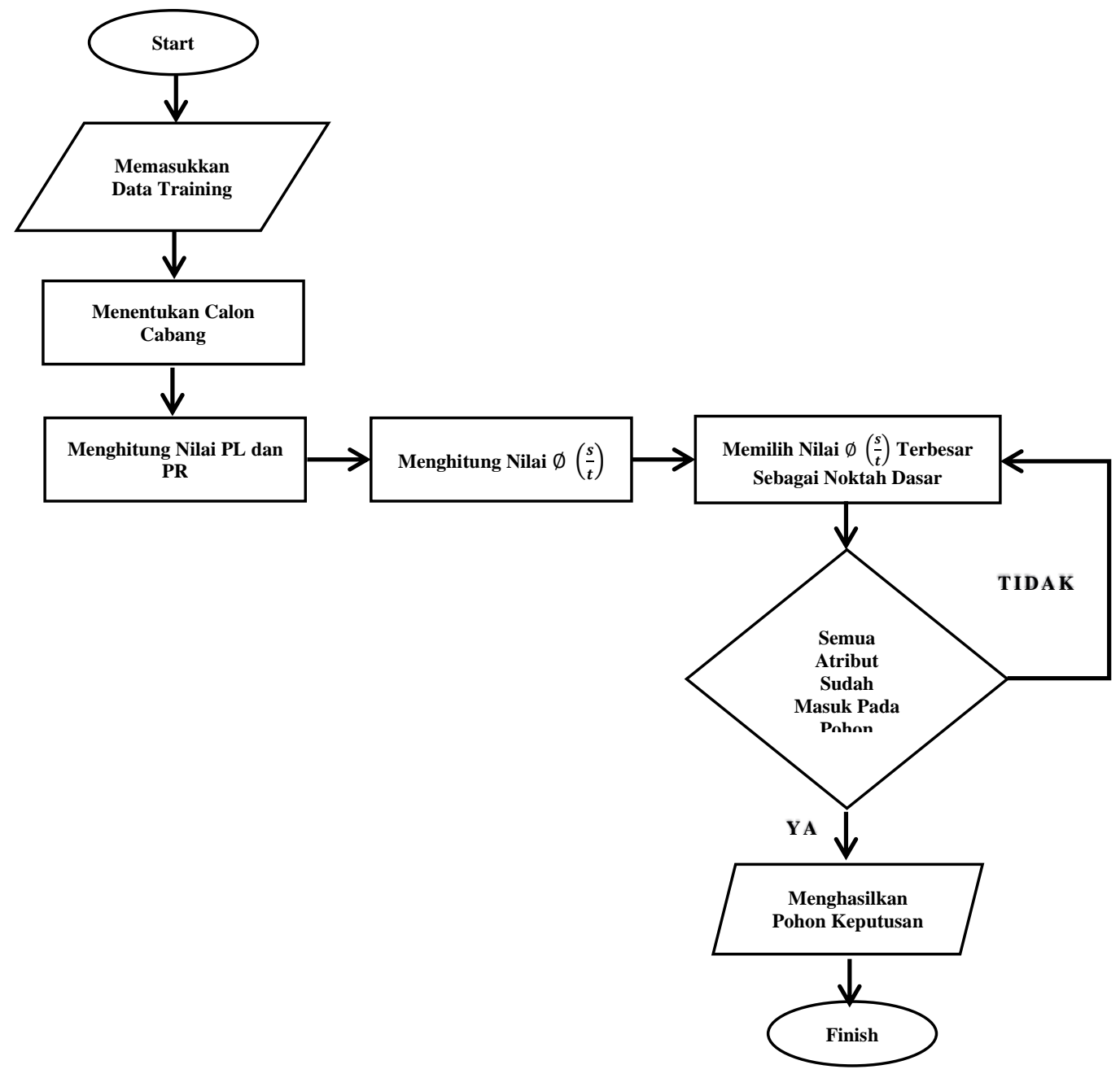

Gambar 3.2 Flowchart CART

\section{Hasil dan Pembahasan}

\section{A. Hasil Penelitian}

Setelah peneliti melakukan penelitian di Lion Parcel Blitar dengan metode wawancara, observasi dan dokumentasi, dapat dipaparkan data sebagai berikut, dimana data yang dimaksud merupakan data untuk perhitungan penggajian kurir yang di sajikan dalam bentuk tabel 4.1

Tabel 1 Tabel Paparan Data

\begin{tabular}{cccccr}
\hline No & Nama & Presensi & In & Out & Kasbon \\
\hline 1. & Firma & 31 & 597 & 6.217 .000 & - \\
\hline 2. & Endra & 31 & 482 & 1.503 .000 & 150.000 \\
\hline
\end{tabular}


Procedia of Engineering and Life Science Vol. 2. No. 1 Oktober 2021

Seminar Nasional \& Call Paper Fakultas Sains dan Teknologi (SENASAINS 2nd)

Universitas Muhammadiyah Sidoarjo

\begin{tabular}{clcclr}
\hline No & Nama & Presensi & In & Out & Kasbon \\
\hline 3. & Wahyu & 31 & 476 & 3.214 .500 & - \\
\hline 4. & Amri & 31 & 613 & 5.276 .000 & - \\
\hline 5. & Rifan & 29 & 421 & 1.754 .000 & 200.000 \\
\hline 6. & Dani & 29 & 441 & 2.386 .500 & - \\
\hline 7. & Depi & 31 & 651 & 3.726 .000 & 175.000 \\
\hline 8. & Anik & 27 & 634 & 7.596 .000 & - \\
\hline
\end{tabular}

Pada tabel 1 ini merupakan data dalam satu bulan yang akan di proses untuk perhitungan gaji kurir, diantaranya jumlah hari presensi, jumlah paket incoming yang berhasil dilakukan pengantaran, total harga paket outgoing yang telah di pickup, dan total kasbon kurir. Dalam perhitungan CART (Classification and Regression Tree) mengambil data incoming untuk dijadikan data keputusan.

Selanjutnya adalah pengujian algoritma atau pengujian metode CART (Classification and Regression Tree) menggunakan aplikasi Weka. Sebelum masuk pada aplikasi Weka, penulis akan menampilkan file yang akan dilakukan pengujian. Salah satu atribut yang akan di uji pada perhitungan ini adalah soal banyak atau tidaknya kurir yang mengantar paket incoming. Berikut gambar atau hasil screenshoot dari file tersebut:

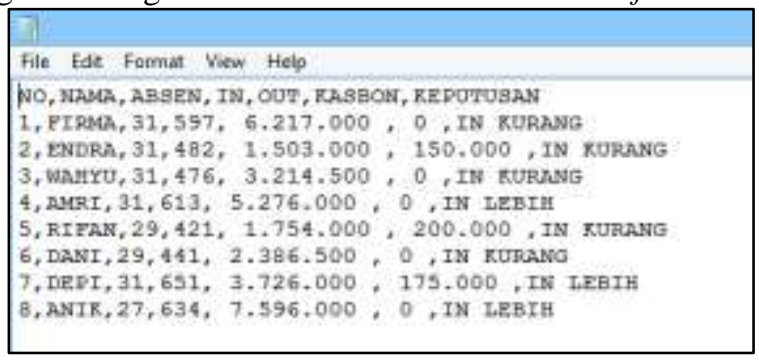

Gambar 3 Data Pengujian

1) Untuk menguji metode CART (Classification and Regression Tree), open file terlebih dahulu. Disini file yang dimasukkan menggunakan format $c s v$.

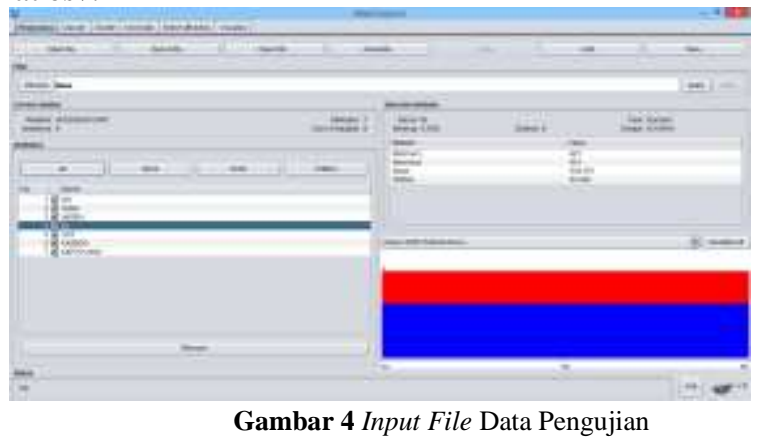

2) Untuk instances atau jumlah data yang digunakan ada 8 data. Atribut yang digunakan ada 7, yaitu 6 atribut sebagai input (no, nama, absen, in, out, kasbon) dan 1 atribut digunakan sebagai output (keputusan).

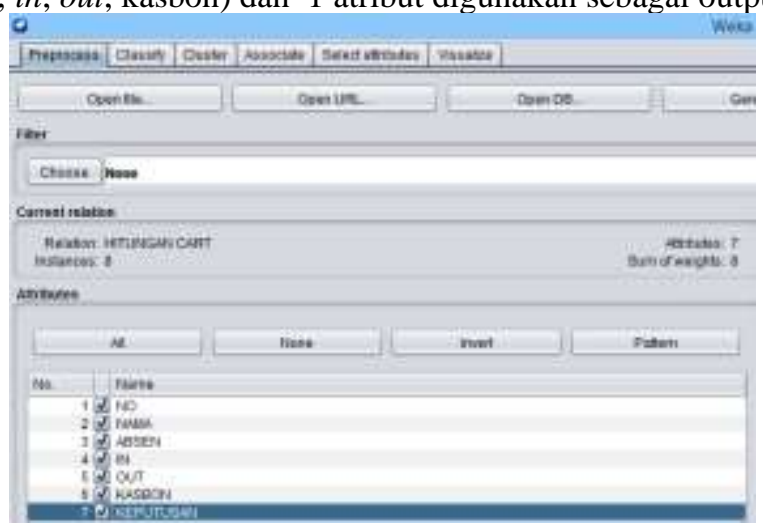

Gambar 5 Current Relation

3) Pada atribut keputusan, untuk value output-nya, yaitu terdapat "in kurang” (kurir yang tidak jumlah pengiriman) dan "in lebih" (kurir yang memenuhi jumlah pengiriman). Pada count dan weight, untuk in kurang terdapat 5 kurir 
Procedia of Engineering and Life Science Vol. 2. No. 1 Oktober 2021

Seminar Nasional \& Call Paper Fakultas Sains dan Teknologi (SENASAINS 2nd)

Universitas Muhammadiyah Sidoarjo

yang tidak memenuhi jumlah pengiriman, sedangkan pada in lebih terdapat 3 kurir yang memenuhi jumlah pengiriman.

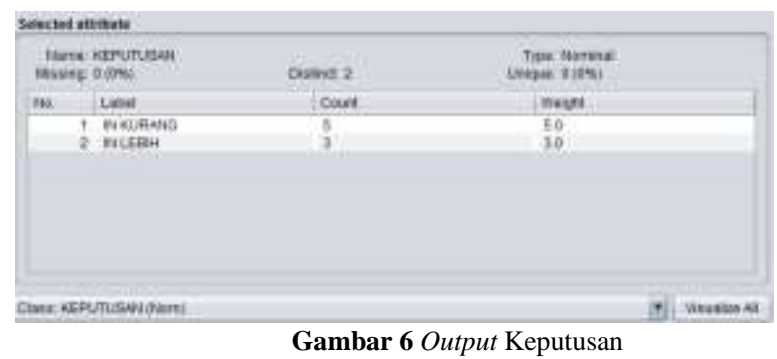

4) Selanjutnya pilih classify. Dikarenakan menggunakan metode CART (Classification and Regression Tree), maka pada pilihan choose pilih trees J48. Untuk output juga disesuaikan, yaitu pilih (Nom) keputusan. Kemudian jalankan dengan tombol start.

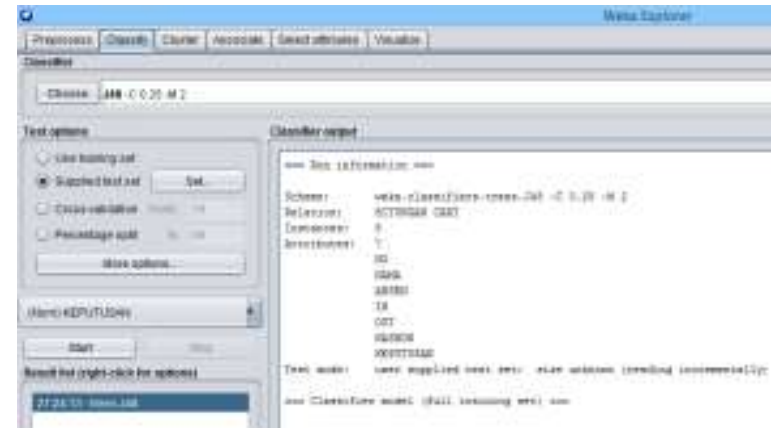

Gambar 7 Pemilihan Jenis Metode atau Algoritma

5) Berikut merupakan output pengujian dari metode CART (Classification and Regression Tree).

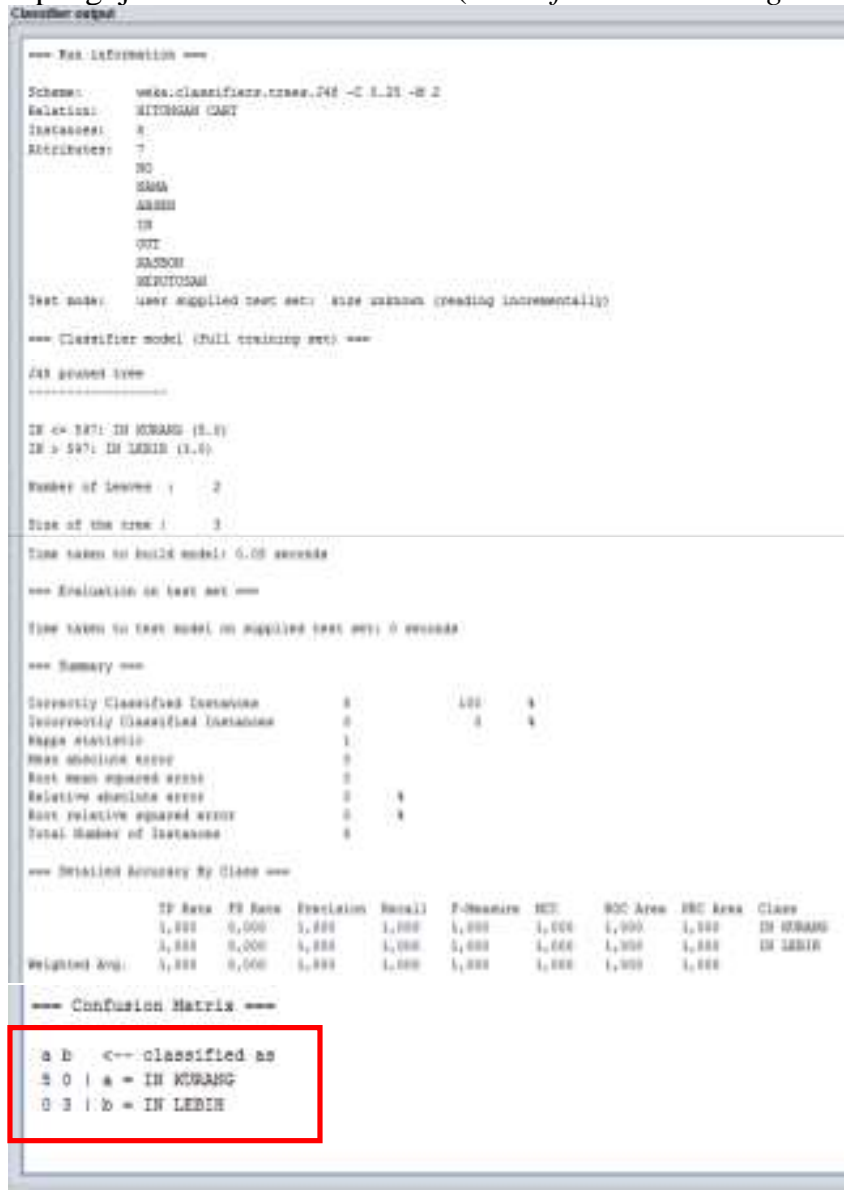

Gambar 8 Output Pengujian Weka 
6) Pada output tersebut sudah terlihat dan sesuai dengan data yang sudah dijelaskan, yaitu terdapat instance sebesar 8 data dan 7 atribut. Untuk confusion matrix terdapat kelas a dan kelas b. Kelas a menunjukkan "in kurang" dengan nilai 5, dan kelas b menunjukkan "in lebih" dengan nilai 3.

7) Jika ingin menampilkan pohon keputusan, maka pilih visualize tree dan akan muncul gambar seperti di bawah ini:

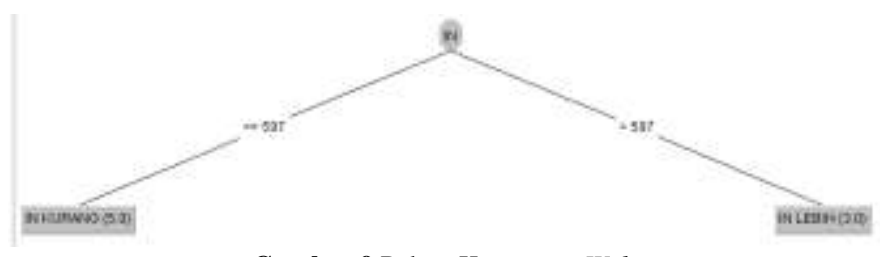

Gambar 9 Pohon Keputusan Weka

8) Keterangan dari in kurang yaitu kurir yang dalam satu bulannya menuntaskan paket dibawah 600 paket, sedangkan in lebih yaitu kurir yang dalam satu bulannya menuntaskan paket lebih dari 600 paket.

\section{B. Pembahasan}

Berdasarkan hasil pengujian Metode CART (Classification and Regression Tree) yang menggunakan aplikasi Weka, maka hasil perhitungan secara manual dan menggunakan aplikasi Weka sudah sesuai. Yaitu dengan menggunakan 8 data dan 7 atribut. 6 atribut digunakan sebagai input (no, nama, absen, in, out, kasbon) dan 1 atribut digunakan sebagai output (keputusan). Keputusan yang digunakan pada pengujian ini adalah untuk melihat banyak atau sedikitnya jumlah incoming yang diproses oleh kurir Lion Parcel selama satu bulan. Sehingga dari 8 total kurir Lion Parcel, 5 diantaranya mengantar dan menjemput paket kurang dari sama dengan 600 paket, dan 3 diantaranya mengantar dan menjemput paket lebih dari 600 paket.

\section{KESIMPULAN}

Berdasarkan hasil yang telah di kemukakan, maka dapat disimpulkan sebagai berikut:

1. Perancangan penggajian aplikasi kurir Lion Parcel Blitar sudah berhasil dilakukan dengan menggunakan bahasa pemrograman PHP (Hypertext Preprocessor). Indikator dari keberhasilan aplikasi ini diantaranya: a. Segi tampilan yang menarik dan mudah dipahami, b. Kebermanfaatan fitur presensi sebagai acuan penggajian harian, c. Sistem penggajian yang akurat dan cepat.

2. Pengujian aplikasi yang dilakukan untuk memecahkan persoalan dalam penghitungan gaji kurir Lion Parcel yaitu dengan cara pengujian menggunakan Black Box dengan hasil presentase pengujian sebesar 92.3\%. Selanjutnya pengujian metode CART (Classification and Regression Tree) dengan hasil akhir confusion matrix kelas a ( <= 600 ) sebesar 5 data dan confusion matrix kelas b ( > 600 ) sebesar 3 data, pengujian kepada validator sebesar $86.1 \%$, dan pengujian kepada calon pengguna sebesar $90.4 \%$. Hal ini menurut penelitian dari Pradya Wibawa, Ratnaya, \& Santiyadnya (2020), aplikasi dinyatakan sangat layak.

3. Dengan melihat hasil pengujian yang telah dilakukan, maka diperoleh unjuk kerja perancangan aplikasi penggajian kurir Lion Parcel Blitar yang menggunakan metode CART (Classification and Regression Tree) melalui tahapan pencarian kelompok data berdasarkan hasil pengantaran incoming yang dikerjakan oleh kurir. Hasil akhirnya akan terlihat pada pohon keputusan dengan hasil nilai cabang kiri (pengantaran incoming paling sedikit) terdapat 5 kurir dan cabang kanan (pengantaran incoming terbanyak) terdapat 3 kurir. Sehingga metode ini cocok dilakukan untuk melakukan penelitian pada sistem penggajian kurir Lion Parcel Blitar.

\section{REFERENSI}

[1]. Agwil, W., Fransiska, H., \& Hidayati, N. (2020). Analisis Ketepatan Waktu Lulus Mahasiswa Dengan Menggunakan Bagging CART. FIBONACCI: Jurnal Pendidikan Matematika dan Matematika, 6(2), 155-166.

[2]. Anggraeni, E. Y., \& Irviani, R. (2017). Pengantar Sistem Informasi. Yogyakarta: CV. Andi Offset.

[3]. Amzah, N. A., Baihaqie, A. D., \& Aruan, M. C. (2021, January). Aplikasi Penggajian Guru dan Karyawan SMK Amaliyah Jakarta Berbasis Java Netbeans. In Semnas Ristek (Seminar Nasional Riset dan Inovasi Teknologi) (Vol. 5, No. 1).

[4]. Ardianto Moenir, F. Y. (2017). Perancangan Sistem Informasi Penggajian Berbasis Web . Jurnal Informatika Universitas Pamulang, 127137.

[5]. Arief, S., Safi'i, I., \& Laela, N. (2019, Juli). Mekanisme Pembuatan Flowchart Penerimaan Pinjaman (Angsuran) Pada (BUMDES) di Desa Pomahan Kecamatan Pulung Kabupaten Ponorogo. : Jurnal Karya Pengabdian Dosen dan Mahasiswa, III(3), 259-264.

[6]. Binjori, A. S. (2020). Implementasi Data Mining Untuk Pengembangan Sistem Rekomendasi Pemilihan SMK Dengan Menggunakan Algoritma CART. KLIK: Kajian Ilmiah Informatika dan Komputer, 1(2), 42-48.

[7]. Desi, Sagala, E., \& Elidawati. (2018). Analisis PPH 21 Terhadap Gaji Karyawan Pada PT. Kencana Utama Sejati. Jurnal Bisnis Kolega, $55-63$. 
Procedia of Engineering and Life Science Vol. 2. No. 1 Oktober 2021

Seminar Nasional \& Call Paper Fakultas Sains dan Teknologi (SENASAINS 2nd)

Universitas Muhammadiyah Sidoarjo

[8]. Indrawan, I. K., Sinarwati, N. K., \& Sujana, E. (2017). Analisis Sistem Pengendalian Intern Pada Penggajian Karyawan PT PLN (PERSERO) Area Bali Utara. e-Journal S1 Ak Universitas Pendidikan Ganesha, 8(2).

[9]. Irawan, I. (2021). Peningkatan Performa Algoritma CART dengan Seleksi Fitur Menggunakan ABC untuk Penilaian Kredit. JATISI (Jurnal Teknik Informatika dan Sistem Informasi), 8(1), 199-208.

[10]. Monalisa, S., \& Hadi, F. (2020). Penerapan Algoritma CART Dalam Menentukan Jurusan Siswa di MAN 1 Inhil. Jurnal Sisfokom (Sistem Informasi dan Komputer), 9(3), 387-394.

[11]. Ningrum, F. C., Suherman, D., Aryanti, S., Prasetya, H. A., \& Saifudin, A. (2019). Pengujian Black Box pada Aplikasi Sistem Seleksi Sales Terbaik Menggunakan Teknik Equivalence Partitions. Jurnal Informatika Universitas Pamulang, 4(4), 125-130.

[12]. Pahira, W., \& Haryono, W. (2020). Rancang Bangun Sistem Aplikasi Penggajian Berbasis Web Dengan Menggunakan Model Waterfall. JOAIIA: Journal of Artificial Intelligence and Innovative Applications, 1(4), 195-203.

[13]. Pradya Wibawa, Ratnaya, \& Santiyadnya. (2020). Pengembangan Media Pembelajaran Air Conditioner (AC) Split Pada Mata Kuliah Teknik Pendingin. Jurnal Pendidikan Teknik Elektro Undiksha, 1-9.

[14]. Putri, W. A. (2018). Standar Pemberian Gaji Guru Honor dalam Perspektif Ekonomi Islam (Studi Kasus SD Negeri 2 Tanjung Rejo Way Kanan). Doctoral dissertation, IAIN Metro.

[15]. Rahmi, I., \& Yozza, H. (2020, Maret). Analisis Kausal Masa Studi Mahasiswa Program Studi Matematika Universitas Andalas Dengan Menggunakan Metode CART. Jurnal Matematika, Sains, dan Teknologi, 21(1), 22-34.

[16]. Shandi, Y. J. (2020). Rekayasa Perangkat Lunak Pengenal Binatang Menggunakan Metode CART. Media Informatika, 19(2), 38-50.

[17]. Siregar, A. B., Buulolo, E., \& Ginting, P. (2017). Pemanfaatan Algoritma Classification and Regression Tress (CART) Untuk Memprediksi Omset Spanduk Pada CV. Moeha Advertising. KOMIK (Konferensi Nasional Teknologi Informasi dan Komputer), 347-354.

[18]. Siregar, H. F., Siregar, Y. H., \& Melani. (2018, Desember). Perancangan Aplikasi Komik Hadist Berbasis Multimedia. Jurnal Teknologi Informasi, 2, 113-121.

[19]. Siregar, I. K., \& Taufik, F. (2017, Agustus). Perancangan Aplikasi SMS Alert Berbasis Web. Jurnal Informatika Merdeka Pasuruan, II(2), $62-70$.

[20]. Soufitri, F. (2019). Perancangan Data Flow Diagram Untuk Sistem Informasi Sekolah (Studi Kasus Pada Smp Plus Terpadu). Regional Development Industry \& Health Science, Technology and Art of Life, 24-246.

[21]. Suwardika, G., Suniantara, I. K., \& Hendayanti, N. P. (2019). Ketidaktepatan Waktu Kelulusan Mahasiswa Universitas Terbuka Dengan Metode Boosting CART. Jurnal Varian, 37-46.

[22]. Tanjung, R. H., \& Kartiko, K. (2017). Penerapan Metode CART (Classification And Regression Trees) untuk Menentukan Faktor - Faktor yang Mempengaruhi Pembayaran Kredit oleh Nasabah (Studi Kasus Bank BRI Unit Aek Tarum-Sumatera Utara). Jurnal Statistika Industri dan Komputasi, 2(02), 78-83.

[23]. Wignyowiyoto, I., \& Rofiah, S. (2017). Sistem Informasi Penggajian Karyawan Berbasis Desktop. Bina Insani ICT Journal, 4(2), 179 188.

[24]. Zain, Pratiwi, F. E., \& Ismaini. (2014). Klasifikasi Pengangguran Terbuka Menggunakan CART (Classification and Regression Tree) di Provinsi Sulawesi Utara. Jurnal Sains dan Seni POMITS, 54-59.

[25]. Zainah, R. (2020). Penerapan Model Pembelajaran Discovery Learning Untuk Meningkatkan Pemahaman Teks Laporan Observasi. Jurnal Ilmu Kependidikan, 39-48. 